\title{
Prediction of Resilience of Adolescents Whose Parents Are Divorced
}

\author{
Yunus Altundağ', Sefa Bulut ${ }^{2}$ \\ ${ }^{1}$ Bolu Atatürk Anatolian High School, Bolu, Turkey \\ ${ }^{2}$ Department of Counseling Psychology and Guidance, School of Educational Sciences, College of Education, \\ Abant Izzet Baysal University, Bolu, Turkey \\ Email: sefabulut22@hotmail.com
}

Received 23 April 2014; revised 21 May 2014; accepted 17 June 2014

Copyright ( 2014 by authors and Scientific Research Publishing Inc.

This work is licensed under the Creative Commons Attribution International License (CC BY).

http://creativecommons.org/licenses/by/4.0/

(c) (i) Open Access

\section{Abstract}

The purpose of this study is to examine the predictive effect of life satisfaction and loneliness level of adolescents with divorced parents on resilience. The study has been carried out on 144 adolescents, 75 of whom are female and 69 are male, and whose parents are officially divorced. The study group consisted of students who are attending different types of high schools in the city of Bolu central districts. Loneliness Scale, Life Satisfaction Scale and Adolescents Resilience Scales were utilized in the data collection process. Pearson Moment Correlation and Multiple Regression analyses were used in data analysis. The results revealed that, while there was a positive relationship between resilience and life satisfaction, a strong negative relationship was found between their resilience and loneliness level of the adolescents whose parents are divorced. Regression analysis revealed that, while loneliness was a significant predictor on resilience, life satisfaction was not a significant predictor of resilience. The findings of this research were discussed within the scope of the related literature.

\section{Keywords}

Resilience of Adolescence, Life Satisfaction, Loneliness, Children from Divorced Families, Adolescence

\section{Introduction}

Although divorce is discouraged by almost any society, it still appears as a phenomenon that always exists. While Turkey is rather behind in divorce rates compared to many other countries, the divorce rate has been drastically increasing in the recent years. The increase of socio-economic status and improvement of cultural level, the changes and new expectations in marital roles, participation of women in work force, the changes emerging 
in dimensions such as communication between spouses and expectations from marriage play an important role in the increase rates of divorce (Arıan, 1996; Hernandez, 1997). Besides, nowadays divorce is evaluated more tolerantly in society than earlier decades (Yazıcıoğlu, 1995).

Although divorce may seem like an issue between husband and wife, it can affect other family members; such as, children being the most at risk and even the other individuals connected with the divorced individuals. It is almost impossible that this condition of the individuals who go through pretty hard periods after divorce does not have an impact on their children. Although a few, there can be divorces with relatively less problems. However, most of the divorces take place under the shadow of conflicts, quarrels, and power struggles. Individuals get exhausted and damaged in many aspects during this period which virtually turns into a war. At this point, children are inversely affected to the greatest degree. Parents who are only interested in their own problems and struggle usually neglect their children and ignore their needs and problems. They might even try to "use" their children in these power struggles and conflicts. After this point, the divorce may become more challenging for the children.

The most common reactions children and adolescents develop after divorce are as follows: sadness, fear, anxiety, feeling of abandonment, anger and desire of conciliation-reconciliation (Benedek \& Brown, 1997). Also, divorce may cause poor school performance and significant behavioral problems in children (Babalis, Tsoli, Nikolopoulos, \& Maniatis 2014). Steinberg (2007) indicated that children in pre-school period and adolescents are mostly affected by the divorce. It is obvious that not only the ones whose parents got divorced in adolescence but also the ones whose parents got divorced long before adolescence are affected negatively (Walczak \& Burns, 2004).

In modern societies, individuals and adolescents can often face difficult life events. Besides natural disasters, such as earthquake and flood, they can encounter serious life problems, such as; the loss of a close relative or parents, the separation of the parents, changing the school or city. While most adolescents may have difficulty in such difficult life events, some of them are more capable to adjust quickly and recover or not to get affected too much. The most essential factor in this adjustment is the phenomenon of resilience which is an ongoing process and requires the individuals to take some steps, effort and time (Masten, 2001).

When the related literature is examined, it is observed that a unanimous definition regarding the phenomenon of resilience is not reached. Walsh (2006) defined resilience as "an active process which enables the individuals getting out of the situation stronger when encountered a difficulty, making progress in a crisis situation and being resilient”; Masten (1994), defined resilience as "adjusting successfully despite risky situations and difficulties”. On the other hand, Fraser, Richman and Galinsky (1999) defined resilience as getting positive and even unexpected achievements under difficult conditions and the ability to adjust extraordinary conditions and situations. Similarly, it was defined as positive adjustment and maintaining or regaining mental health despite difficult life events (Wald, Asmundson, \& Stapleton, 2006). The researchers defined basic components; such as, existence of troubled or difficult life events and adjusting this life, and being able to deal with this difficult life events. Therefore, resilience can be conceptualized as, adjusting to a difficult life experience, and dealing with it in an efficient way.

The happiness of a person and the conditions that provide happiness has been an interesting subject for psychologists. Currently, happiness is examined within the frames of "psychological well-being", "subjective wellbeing”, "life quality", "life satisfaction" and "positive sensation” (Tuzgöl-Dost, 2007). Happiness or subjective well-being is being used interchangeably in the literature, and they are defined as a cognitive and emotional evaluation of an individual's life (Diener, 1984, 1995). Happiness or subjective well-being is defined as the existence of positive feelings in terms of perceived quality of life or life satisfaction; or the absence of negative feelings (Diener, 1984). Life satisfaction is defined as the positive, subjective and general evaluation of the life of an individual as a whole or evaluation of particular fields of his/her life (family life, school experiences etc.) (Diener, Suh, Lucas, \& Smith, 1999). General life satisfaction has been defined as a cognitive evaluation of an individual's life as a whole (Huebner, 2004). Even though temporary feelings affect life satisfaction, life satisfaction differs from temporary emotional expressions. Life satisfaction is defined as a more general state which covers all or a big portion of the individual's life.

Life satisfaction is an important indicator that shows what kind of a mental health state the individual is generally in. Various inhibitions, difficulties, conflicts and sudden negative changes occurring in life may decrease the level of life satisfaction (Demirel \& Canat, 2004). The lack or shortage of life satisfaction level causes various negative results which include mental and physical health problems (Huebner, 2004). 
Although hundreds of studies were conducted about life satisfaction of adults (Diener, 1984; Diener \& Diener, 1995), life satisfaction of childhood has only drawn attention recently. Most recent studies showed the importance of life satisfaction in understanding the psychological well-being of children and adolescents. It is probably a difficult process to completely understand the relations and their determinants in life satisfaction in adolescents. Adolescents often have biological and psycho-social changes as a result of fluctuations in their selfrespect/sufficiency in different development areas as they grow up and the increasing social pressure may cause their life satisfaction to decrease and they get into depression (Paxton, Valois, Huebner, \& Drene, 2006). At this point, unless there are protective factors, adolescents resort to ineffective or inappropriate coping behaviors (i.e. substance addiction, aggressive behavior) (Valois, Zulling, Huebner, \& Drane, 2004). On the other hand, the individual attempting to risky behaviors which would threaten his/her health may affect the life satisfaction of the person negatively (Zullig, Pun, \& Huebner, 2007). Similarly, self esteem and family support positively affect adolescents' life satisfaction and restrain them from drug abuse (Gutiérrez \& Romero, 2014).

The concept of loneliness has been studied extensively. According to Perlman and Peplau (1984), loneliness is an unpleasant emotional state which is experienced as a result of the difference between the individual's existing and desired social relations. Loneliness can be experienced in negative, uncomfortable and even painful ways; it is a common, depressive and weakening situation which can affect the life of every individual (Killeen, 1998). Researchers believe that the individuals have two essential needs in their relations with others; commitment and belongingness. While the need for commitment is seen as the individual's need to share his/her life with someone (s)he is in a close relationship, the need for belonging is seen in the form of feeling like a part of a group or community, being able to share the attention, value and norms. Loneliness is experienced in cases where these two needs are not met (Prezza \& Pacilli, 2007).

As for loneliness in adolescents; it is defined as a situation which arises with anxiety and negative feelings that are caused by being inadequate in social relations with peers. In spite of not having any pathological effects when seen occasionally, when it is experienced often it also reflects on other areas of the adolescent's life regarding his/her adjustment (Asher \& Paquette, 2003). Previous studies show that peer acceptance and exclusion by peers are closely related to the feeling of loneliness in adolescence period (Mouratidis \& Sideridis, 2009).

Adolescents may experience loneliness for many different reasons. Generally, the risk factors for loneliness can be in the form of bullying, depression, social skill deficit, exclusion and feeling troubled (Krause-Parello, 2008). Changing social environment can also be an important factor for adolescents in experiencing loneliness. It is obvious that the relationship with the family, social support, shyness and self-confidence are related to the feeling of loneliness (McWhirter, Besett, Horibate, \& Gat, 2002). Individuals who have close relationship with the family, are self-confident, have access to social support sources and have low level of shyness; have lower levels of loneliness. The study of Kilınç and Sevim (2005) shows that some traits of adolescents such as low self-respect, social anxiety, negative perception and interpretation of other's intentions and interactions of others, having negative opinion about the self and others and distrust prevent them from attempting for establishing interpersonal communications and prevent them to develop relationships.

In this study, it is aimed to examine the relation between resilience, life satisfaction and loneliness levels of with adolescents, whose parents are officially divorced. Also, it was investigated if loneliness and life satisfaction have predictive effects on resilience.

\section{Method}

\subsection{Sample}

The participants of the study were the 9th, 10th, 11th and 12th grade students who are attending the high schools in Bolu in the academic year of 2012-2013. Initially, it was attempted to include all high schools in Bolu but not all of them were accessible due to different reasons. Therefore, random sampling method was used in school selection. The study was carried out in 11 high schools in total including five Anatolian High Schools, one Teacher High School, one Regular High School and four Vocational High Schools. 144 students who study in these schools and whose parents were officially divorced have participated in the study.

\subsection{Process}

First of all, the necessary permissions were obtained from the Provincial Directorate of National Education. The students whose parents were officially divorced were identified by the help of psychological counselors working 
at the participating schools. The students were informed about the voluntary nature of the study, and it was okay if they chose to not to participate in the study. The confidentiality was also explained and they were told that the research protocols would be seen only by the researcher and will not be shared with their teachers and school administrators. Then, consent forms were obtained from the students who chose to take part in the study and form their parents. The study was carried out with the adolescents who were willing and whose parents permitted. It took approximately 30 to 40 minutes, a class period to fill out the instruments. The author went to their classrooms and administered the instruments by himself, walked around the classrooms and answered any question the students might have asked. Then the data was collected in envelopes and entered in computer. Confidentiality was protected in each step of research and data analysis.

\subsection{Instruments}

\subsubsection{Demographic Information Form}

A personal information form was constructed for the demographic information on adolescents about their sex, school, family status, number of friends and siblings by the researchers.

\subsubsection{Adolescent Resilience Scale}

The research instrument is developed by Bulut, Doğan and Altundağ (2013) and consists of 29 items and six sub-dimensions. These sub-dimensions are family support, peer support, determination of struggle, adaptation and empathy. This instrument was developed by the researchers in order to determine the high school students' resilience levels. Exploratory Factor Analysis (EFA) was conducted for construct validity. It was found that the factor loadings of the items in the scale changed between .51 and .82 and it explained $56.99 \%$ of the total variance. As for the criterion validity, it was found that Adolescent Resilience Scale shows $-.47(p<.001)$ correlation with Problem Solving Inventory, $-.46(p<.001)$ correlation with Focus of Control Scale and -.61 $(p<.001)$ correlation with Beck Despair Scale.

For the reliability study, test-retest was conducted after a month again and .87 correlations was found. Cronbach's Alpha internal consistency coefficients were found, .87 for the whole of the scale, .89 for the "family support" dimension, .84 for the "peer support" dimension, .81 for "school support" dimension, .70 for "adaptation" dimension, .67 for "determination of struggle" dimension and .61 for "empathy" dimension.

\subsubsection{Life Satisfaction Scale}

The Life Satisfaction Scale (LSS) developed by Diener, Emmons, Larsen ve Griffin (1985) [The Satisfaction with Life Scale (SWLS)] is used to measure the life satisfaction of the participating adolescents. This scale is developed in order to determine the satisfaction that the individuals get from their lives. Life Satisfaction Scale is a 7 grade Likert type scale. The high points obtained from the scale indicate that the life satisfaction is high. Diener, et al. (1985) found the reliability of the scale as Alpha $=.87$ and criterion referenced validity as .82 in the original study. In previous study, the scale was adopted to the Turkish population in Turkey by Yetim (2001) and reliability Cronbach Alpha correlation was found as .86 and test-retest reliability as .73. In this current study the reliability correlation of the scale was calculated and Cronbach Alpha value was found as .84.

\subsubsection{Loneliness Scale}

First the instrument was developed by Russell, Peplau and Ferguson (1978) and later revised by Russell, Peplau and Cutrona (1980). In the study the revised form utilized as criterion validity. Significant correlation was found a the level of .62 UCLA Loneliness Scale and Beck Depression Scale and .62 between the Costello-Comrey Depression Scale and .32 between Costello-Comrey Anxiety Scale. In the original scale the the internal consistency coefficient was .96 and test-retest reliability was .73 after two months interval.

Demir (1989) found .77 correlation with the Beck Depression Scale and .82 correlation with the social introversion sub-dimension of Multiphasic Depression Inventory in the analysis he made for criterion validity in his adaptation study. In the study reliability analysis of, internal consistency coefficient was found to be .96 and testretest revealed a .94 correlation.

\section{Findings}

Pearson correlation coefficient analysis was utilized in order to determine the relationship between the resilience, 
life satisfaction and loneliness level of adolescents who are coming from divorced families and broken homes.

As it was shown in Table 1, there is a strong negative correlation $(-.70)$ between life satisfaction and loneliness and positive correlation (.40) with empathy. There are also a set of positive correlations between life satisfaction and determination of struggle (.71), adaptation (.54), school support (.17), peer support (.68), and family support (.64).

In order to determine if life satisfaction and loneliness levels predict resilience Multiple Regression analysis was done. The results are shown in Table 2.

There is a positive relation $(r=.65)$ between life satisfaction and resilience when dual and partial correlations between predicting and dependent (predicted) variables are examined; on the other hand, when other variables are controlled, the correlation between the two variables is found as $r=.007$. There is a quite strong negative relation ( $\mathrm{r}=-.92$ ) between loneliness and resilience. Also when the other variable (life satisfaction) was controlled, again, a strong negative relation $(\mathrm{r}=-.85)$ was found.

Life satisfaction and loneliness variables together, give a quite high and significant relation with resilience score. $\mathrm{R}=.918, \mathrm{R}^{2}=.84, p<.01$. These two variables together, explain $84 \%$ of the total variance in resilience.

According to the standardized regression coefficient $(\beta)$, the relative importance order of the predicting variables as; loneliness and life satisfaction. But when the analysis results regarding the significance of regression coefficients are examined, it is seen that only the loneliness variable is a significant predictor on resilience. Life satisfaction variable does not have a significant effect.

\section{Discussion}

There are few studies investigating the correlation between resilience, life satisfaction and loneliness. However, studies conducted on resilience are focused on self-respect, problem solving and coping ability. In an experimental study where life satisfaction and coping ability, a close concept to resilience, are examined, it was found that coping training has a positive effect on life satisfaction (Gümüşbaş, 2008). Again, in another study where

Table 1. Correlation of resilience, life satisfaction and loneliness levels in adolescents.

\begin{tabular}{|c|c|c|c|c|c|c|c|c|c|}
\hline Variables & 1 & 2 & 3 & 4 & 5 & 6 & 7 & 8 & 9 \\
\hline Life satisfaction & 1 & & & & & & & & \\
\hline Loneliness & $-.70^{* *}$ & 1 & & & & & & & \\
\hline Family support & $.64^{* *}$ & $-.86^{* *}$ & 1 & & & & & & \\
\hline Peer support & $.68^{* *}$ & $-.89^{* *}$ & $.87^{* *}$ & 1 & & & & & \\
\hline School support & $.17^{*}$ & $-.55^{* *}$ & $.59^{* *}$ & $.53^{* *}$ & 1 & & & & \\
\hline Adaptation & $.54^{* *}$ & $-.83^{* *}$ & $.77^{* *}$ & $.79^{* *}$ & $.52^{* *}$ & 1 & & & \\
\hline Determination of struggle & $.71^{* *}$ & $-.79^{* *}$ & $.74^{* *}$ & $.77^{* *}$ & $.40^{* *}$ & $.72^{* *}$ & 1 & & \\
\hline Empathy & $.40^{* *}$ & $-.67^{* *}$ & $.65^{* *}$ & $.70^{* *}$ & $.43^{* *}$ & $.69^{* *}$ & $.51^{* *}$ & 1 & \\
\hline Total resilience & $.64^{* *}$ & $-.91^{* *}$ & $.94^{* *}$ & $.93^{* *}$ & $.69^{* *}$ & $.88^{* *}$ & $.83^{* *}$ & $.74^{* *}$ & 1 \\
\hline
\end{tabular}

Note: ${ }^{* *}=p<0.01 ;{ }^{*}=p<0.05$

Table 2. Regression analysis for prediction of resilience of adolescents whose parents are divorced.

\begin{tabular}{|c|c|c|c|c|c|c|c|}
\hline Variables & B & Standard error & $\beta$ & $\mathrm{T}$ & $p$ & Dual r & Partial r \\
\hline \multirow{3}{*}{$\begin{array}{c}\text { Stable } \\
\text { life satisfaction } \\
\text { loneliness }\end{array}$} & 131.749 & 4.967 & & 26.52 & .000 & & \\
\hline & -.010 & .128 & -.004 & -.078 & .938 & .647 & .007 \\
\hline & -1.126 & .058 & -.920 & -19.43 & .000 & -.918 & -.853 \\
\hline $\mathrm{R}=.918$ & $\mathrm{R}^{2}=.842$ & & & & & & \\
\hline$F_{(2,141)}=375.843$ & $p=.000$ & & & & & & \\
\hline
\end{tabular}


resilience and emotional intelligence and hope levels of university students are examined, a medium level positive correlation was found between emotional intelligence and hope level and resilience (Aydın, 2010). In a prediction study, self-respect predicted loneliness and a high correlation were found between those two variables (Koçak, 2008).

In a recent study, researchers found a positive correlation between emotional intelligence and life satisfaction, and a mediating correlation between emotional intelligence and resilience (Liu, Wang, \& Lu, 2013). However, there are other studies found a strong and positive correlation between life satisfaction and resilience (Beutel, Glaesmer, Wiltink, Marian, \& Brahler, 2010). Similarly, a more recent study suggested a high correlation between personal, social and general life satisfaction and resilience (Gutiernez \& Romero, 2014). In this study with Turkish adolescents, despite the fact that there is average correlation (.64) between life satisfaction and resilience, results indicate that life satisfaction is not a predictive factor for resilience. Thus, it can be inferred that higher life satisfaction usually means higher resilience, but it's not always possible to say that higher levels of life satisfaction leads to more resilience. In fact, both life satisfaction and resilience are positive concepts that improve one's ability to cope with negative life events, and existence of one generally explains presence of the other. Yet, findings of this study did not allow us to conclude whether life satisfaction causes resilience or not.

Also, in this current study, loneliness predicted resilience. It was found that as resilience is increased, level of loneliness is decreased. These findings give rise to the thought that isolation can be a risk factor and may have influence on resilience in adolescents. The fact is that variables, such as, peer support, family support, empathy, determination of struggle help to increase resilience. Also, adolescents who may not pose the necessary internal and external sources to cope with difficulties and emotional problems may demonstrate high loneliness level. Thus, loneliness can a very significant variable in explaining resilience in adolescence.

Social and cultural exclusions may negatively affect individuals' well being (Escarbajal-Frutos, Izquierdo-Rus, \& López-Martínez, 2014). However, in Turkish culture, the adolescents whose parents are divorced have a very important social support to decrease and eliminate the feelings of loneliness and social isolation. Close relatives and extended family members such as; grandparents or uncles, aunts can provide social support and compassion for the children and adolescents. In fact, it is very common that divorced adults and their children goes back to their original family and lives with them. And even when, the single parents get marry, the children are taken care of by their grandparents. Close relatives often socialize together and they pay attention to the children from broken homes. Usually, when a divorce occurrs in a family, close relatives and grandparents provide extensive social, financial and emotional support. This plays an important role in decreasing loneliness which is a risk factor for resilience. Similar results were found in a Spanish study, where emotional bound with parents and attachment to peers helped adolescents to cope with effectively (Escarbajal-Frutos, Izquierdo-Rus, \& López-Martínez, 2014). Therefore, it seems that social supports are imperative for children and adolescents dealing with problems associated with divorce. A recent Greek study also supports this notion that, family pattern plays an important role in children emotional development and school achievements (Babalis, et al., 2014).

Internal and external protective factors can play an important role on resilience (Masten, 2001). Internal protective factors on resilience can be listed as: internal locus of control (Allen, Hauser, Bell, \& O'Connor, 2010), self-confidence (Bitsika, Sharpley, \& Peters, 2010), being hopeful (Collins, 2009), self-respect, secure attachment (Mango, Patinas, \& Managua, 2008), having a future oriented goal (Hass \& Grayson, 2009; Hines, Medinger, \& Wyatt, 2005), being spiritually oriented (Chung, 2008), optimism (Teri, 2008), self-sufficiency (Hass \& Graydon, 2009; Terzi, 2008), using problem solving oriented coping strategy (Markstrom, Marshall, \& Tryon, 2000; Terzi, 2008), extroversion, ability to manage the sources efficiently (Agaibi \& Wilson, 2005), active problem solving skill (Carlson, 2001), sensibility, awareness, boldness, stability (Hines, Merdinger, \& Wyatt, 2005) and being responsible (Phan, 2003). These adolescents with divorced parents possessing those protective factors, have the ability to increase their resilience. It seems that resilience is a dynamic, improvable and learnable trait (Luthar, Cicchetti, \& Becker, 2000). Therefore, counseling programs gears to increase resiliency (Gürgan, 2006) and psycho-education programs (Ünüvar, 2012) can be an effective method in the treatment processes.

\section{References}

Agaibi, C. E., \& Wilson, J. P. (2005). Trauma, PTSD and Resilience: A Review of Literature. Trauma Violence Abuse, 6, 195-216. http://dx.doi.org/10.1177/1524838005277438

Allen, J. P., Hauser, S. T., Bell, K. L., \& O’Connor, T. G. (2010). Longitudinal Assessment of Autonomy and Relatedness in 
Adolescent-Family Interactions as Predictors of Adolescent Ego Development and Self-Esteem. Child Development, 65, 179-194. http://dx.doi.org/10.2307/1131374

Arıkan, Ç. (1996). Halkın Boşanmaya İlişkin Tutumları Araştırması. Ankara: Başbakanlık Aile Araştırma Kurumu Yayınları.

Asher, S. R., \& Paquette, J. A. (2003). Loneliness and Peer Relations in Childhood. Current Directions in Psychological Science, 12, 75-78. http://dx.doi.org/10.1111/1467-8721.01233

Aydın, B. (2010). Üniversite Öğrencilerinin Duygusal Zeka ve Umut Düzeyleri İle Psikolojik Sağlamlıkları Arasındaki İlişkinin İncelenmesi. Unpublished Master’s Thesis, Trabzon: Karedeniz Technical University, Social Sciences Institute.

Babalis, T., Tsoli, K., Nikolopoulos, V., \& Maniatis, P. (2014). The Effect of Divorce on School Performance and Behavior in Preschool Children in Greece: An Empirical Study of Teachers’ Views. Psychology, 5, 20-26.

http://dx.doi.org/10.4236/psych.2014.51005

Benedek, E. P., \& Brown, C. F. (1997). Boşanma ve Çocuğunuz (S. Katlan, Trans., 1st Publication). Ankara: HYB Publishers. (Original Study Publishing Date: 1995).

Beutel, M. E., Glaesmer, H., Wiltink, J., Marian, H., \& Brähler, E. (2010). Life Satisfaction, Anxiety, Depression and Resilience across the Life Span of Men. The Aging Male, 13, 32-39. http://dx.doi.org/10.3109/13685530903296698

Bitsika, V., Sharpley, C. F., \& Peters, K. (2010). How Is Resilience Associated with Anxiety and Depression? Analyses of Factor Score Interactions within a Homogeneous Sample. German Journal of Psychiatry, 13, 9-16 http://www.gjpsy.uni-goettingen.de/gjp-article-bitsika.pdf

Bulut, S., Doğan, U., \& Altundağ, Y. (2013). Adolescent Psychological Resilience Scale: Validaty and Reliability Study. Suvremena Psihologija, 16, 21-32.

Carlson, D. J. (2001). Development and Validation of a College Resilience Questionnaire. Unpublished Doctoral Thesis, University of Nebraska, Lincoln.

Chung, H. (2008). Resilience and Character Strengths among College Student. Unpublished Doctoral Thesis, Tucson: University of Arizona.

Collins, A. B. (2009). Life Experiences and Resilience in College Students: A Relationship Influenced by Hope and Mindfulness. Unpublished Doctoral Thesis, Texas A\&M University, College Station.

Demir, A. (1989). U.C.L.A. Yalnızlık Ölçeğinin Geçerlik ve Güvenirliği. Psikoloji Dergisi, 7, 14-18.

Demirel, S., \& Canat, S. (2004). Ankara'daki Beş Eğitim Kurumunda Kendini Yaralama Davranışı Üzerine Bir Çalışma. Kriz Dergisi, 12, 1-9.

Diener, E. (1984). Subjective Well-Being. Psychological Bulletin, 95, 542-575. http://dx.doi.org/10.1037/0033-2909.95.3.542

Diener, E., Emmons, R. A., Larsen, R. J., \& Griffin, S. (1985). The Satisfaction with Life Scale. Journal of Personality Assessment, 49, 71-75. http://dx.doi.org/10.1207/s15327752jpa4901 13

Diener, E., \& Diener, M. (1995). Cross-Cultural Correlates of Life Satisfaction and Self Esteem. Journal of Personality and Social Psychology, 68, 653-663. http://dx.doi.org/10.1037/0022-3514.68.4.653

Diener, E., Suh, E. M., Lucas, R. E., \& Smith, H. L. (1999). Subjective Well-Being: Three Decades of Progress. Psychological Bulletin, 125, 276-302. http://dx.doi.org/10.1037/0033-2909.125.2.276

Escarbajal-Frutos, A., Izquierdo-Rus, T., \& López-Martínez, O. (2014). Analysis of Psychological Well-Being in Groups at Risk of Social Exclusion. Anales de Psicologia, 30, 541-548.

Fraser, M. W., Galinsky, M. J., \& Richman, J. M. (1999). Risk, Protection, and Resilience: Toward a Conceptual Framework for Social Work Practice. Social Work Research, 23, 131-143. http://dx.doi.org/10.1093/swr/23.3.131

Gutiérrez, M., \& Romero, I. (2014). Resilience, Subjective Well-Being and Adolecents’ Attitudes toward Drug Use. Anales de Psicologia, 30, 608-619.

Gümüşbaş, B. (2008). Stresle Başa Çıkma Yollarının İlköğretim İkinci Kademe Öğrencilerinin Stresle Başa Çıkma Yöntemleri ve Yaşam Doyumu Üzerindeki Etkisinin İncelenmesi. Unpublished Master Thesis, Izmir: Dokuz Eylül University Social Science Institute.

Hass, M., \& Graydon, K. (2009). Sources of Resiliency among Successful Foster Youth. Children and Youth Service, 31, 457-463. http://dx.doi.org/10.1016/j.childyouth.2008.10.001

Hernandez, D. J. (1997). Child Development and the Social Demography of Childhood. Child Development, 68, $149-169$. http://dx.doi.org/10.2307/1131933

Hines, A. M., Merdinger, J., \& Wyatt, P. (2005). Former Foster Youth Attending College: Resilience and the Transition to Young Adulthood. American Journal of Orthopsychiatry, 75, 381-394. http://dx.doi.org/10.1037/0002-9432.75.3.381

Huebner, E. S. (2004). Research on Assessment of Life Satisfaction of Children and Adolescents. Social Indicators Research, 
66, 3-33. http://dx.doi.org/10.1023/B:SOCI.0000007497.57754.e3

Kılınç, H., \& Sevim, S. A. (2005). Ergenlerde Yalnızlık ve Bilişsel Çarpıtmalar. Ankara Üniversitesi, Eğitim Bilimleri Fakültesi Dergisi, 38, 69-88. http://dergiler.ankara.edu.tr/dergiler/40/146/1049.pdf

Killeen, C. (1998). Loneliness: An Epidemic in Modern Society. Journal of Advanced Nursing, 28, 762-770.

Krause-Parello, C. A. (2008). Loneliness in the School Setting. The Journal of School Nursing, 24, 66-70. http://dx.doi.org/10.1177/10598405080240020301

Liu, Y., Wang, Z., \& Lu, W. (2013). Resilience and Affect Balance as Mediators between Trait Emotional Intelligence and Life Satisfaction. Personality and Individual Differences, 54, 850-855. http://dx.doi.org/10.1016/j.paid.2012.12.010

Luthar, S.S., Cicchetti, D., \& Becker, B. (2000). The Construct of Resilience: A Critical Evaluation and Guidelines for Future Work. Child Development, 71, 543-562. http://onlinelibrary.wiley.com/doi/10.1111/1467-8624.00164/abstract http://dx.doi.org/10.1111/1467-8624.00164

Mango, C., Parinas, N., \& Mamauag, M. (2008). The Influence of Self-Mastery on Building a Model of Resiliency. Philippine Journal of Counseling Psychology, 10, 1-22.

Markstrom, C. A., Marshall, S. K., \& Tryon, R. J. (2000). Resiliency, Social Support, and Coping in Rural Low-Income Appalachian Adolescents from Two Racial Groups. Journal of Adolescence, 23, 693-703. http://dx.doi.org/10.1006/jado.2000.0353

Masten, A. S. (1994). Resilience in Individual Development: Successful Adaptation Despite Risk and Adversity. In M. C. Wang, \& G. W. Gordon (Eds.), Educational Resilience in Inner-City America (pp. 3-25). Hillsdale, NJ: Lawrence Erlbaum Associates, Inc.

Masten, A. S. (2001). Ordinary Magic: Resilience Processes in Development. American Psychologist, 56, 227-238. http://psycnet.apa.org/doi/10.1037/0003-066X.56.3.227 http://dx.doi.org/10.1037/0003-066X.56.3.227

McWhirter, B. T., Besett-Alesch, T. M., Horibata, J., \& Gat, I. (2002). Loneliness in High Risk Adolescents: The Role of Coping, Self-Esteem, and Empathy. Journal of Youth Studies, 5, 69-84. http://dx.doi.org/10.1080/13676260120111779

Mouratidis, A. A., \& Sideridis, G. D. (2009). On Social Achievement Goals: Their Relations with Peer Acceptance, Classroom Belongingness, and Perceptions of Loneliness. The Journal of Experimental Education, 77, 285-308. http://dx.doi.org/10.3200/JEXE.77.3.285-308

Paxton, R. J., Valois, R. F., Huebner, E. S., \& Drane, W. (2006). Opportunity for Adult Bonding/Meaningful Neighborhood Roles and Life-Satisfaction among USA Middle School Students. Social Indicators Research, 79, 291-312. http://dx.doi.org/10.1007/s11205-005-4129-3

Perlman, D., Peplau, L. A., \& Peplau, L. (1984). Loneliness Research: A Survey of Empirical Findings. In L. A. Peplau, \& S. E. Goldston, (Eds.), Preventing the Harmful Consequences of Severe and Persistent Loneliness (pp. 13-46). US Goverment Printing Office, DDH Publication No: 84-1312.

Phan, T. (2003). Life in School: Narratives of Resiliency among Vietnamese Canadian Youths. Adolescence, 38, 555-566.

Prezza, M., \& Pacilli, M. G. (2007). Current Fear of Crime, Sense of Community, and Loneliness in Italian Adolescents: The Role of Autonomous Mobility and Play during Childhood. Journal of Community Psychology, 35, 151-170. http://dx.doi.org/10.1002/jcop.20140

Russell, D., Peplau, L. A., \& Ferguson, M. L. (1978). Developing a Measure of Loneliness. Journal of Personality Assessment, 42, 290-294. http://dx.doi.org/10.1207/s15327752jpa4203 11

Russell, D., Peplau, L. A., \& Cutrona, C. E. (1980). The Revised UCLA Loneliness Scale: Concurrent and Discriminant Validity Evidence. Journal of Personality and Social Psychology, 39, 472-480. http://dx.doi.org/10.1037/0022-3514.39.3.472

Steinberg, L. (2007). Ergenlikte Aileler. In S. A. Sevim (Ed.), Ergenlik (pp. 149-184). Ankara: İmge Publisher.

Terzi, Ş. (2008). Üniversite öğrencilerinde kendini toparlama gücünün içsel koruyucu faktörlerle ilişkisi. Hacettepe Üniversitesi Ĕ̈itim Fakültesi Dergisi, 35, 297-306. http://www.efdergi.hacettepe.edu.tr/200835\%DEER\%DDFE\%20TERZ\%DD.pdf

Tuzgöl-Dost, M. (2007). Üniversite Öğrencilerinin Yaşam Doyumunun Bazı Değişkenlere Göre İncelenmesi. Pamukkale Üniversitesi Ĕ̆itim Fakültesi Dergisi, 2, 132-142. http://pauegitimdergi.pau.edu.tr/Makaleler/595625694_Meliha\%20Tuzg\%C3\%B6l\%20Dost1.pdf

Valois, R. F., Zullig, K. J., Huebner, E. S., \& Drane, J. W. (2004). Life Satisfaction and Suicide among High School Adolescents. Social Indicators Research, 23, 81-105. http://dx.doi.org/10.1007/978-1-4020-2312-5 5

Wald, J., Taylor, S., Asmundson, G. J., Jang, K. L., \& Stapleton, J. (2006). Literature Review of Concepts: Psychological Resiliency (No. DRDC-CR-2006-073). Vancouver: British Columbia University.

Walczak, Y., \& Burns, S. (2004). Boşanma ve Çocuk Üzerine Etkileri. İ. Ersevim (Trans.), İstanbul: Özgür Publisher. 
(Original study publishing date: 1979.)

Walsh, F. (2006). Strengthening Family Resilience (2nd ed.). New York: Guilford Publications.

Yazıcıŏ̆lu, Y. (1995). Değişen Teknoloji ve Aileye Etkisi. Eskişehir: Anadolu Üniversitesi Açıöğretim Fakültesi Yayınları. Yetim, Ü. (2001). Toplumdan Bireye Mutluluk Resimleri. İstanbul: Bağlam Publishers.

Zullig, K. J., Pun, S. M., \& Huebner, E. S. (2007). Life Satisfaction, Dieting Behavior, and Weight Perceptions among College Students. Applied Research in Quality of Life, 2, 17-31. http://dx.doi.org/10.1007/s11482-007-9027-1 
Scientific Research Publishing (SCIRP) is one of the largest Open Access journal publishers. It is currently publishing more than 200 open access, online, peer-reviewed journals covering a wide range of academic disciplines. SCIRP serves the worldwide academic communities and contributes to the progress and application of science with its publication.

Other selected journals from SCIRP are listed as below. Submit your manuscript to us via either submit@scirp.org or Online Submission Portal.
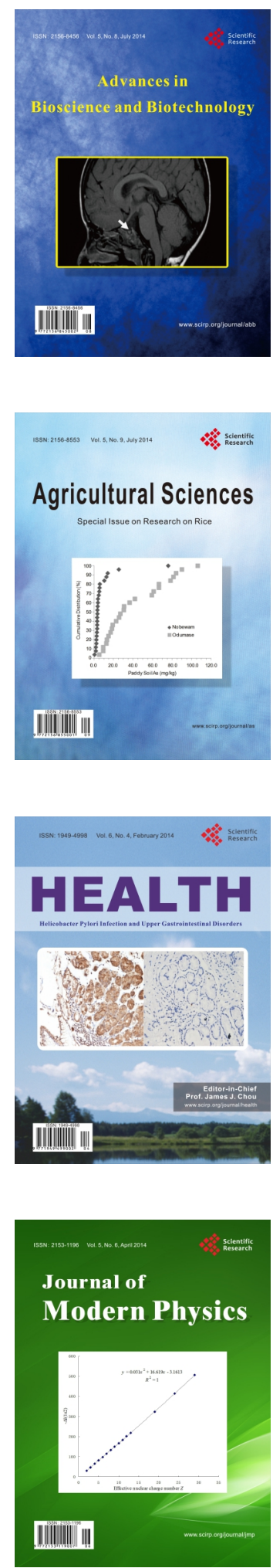
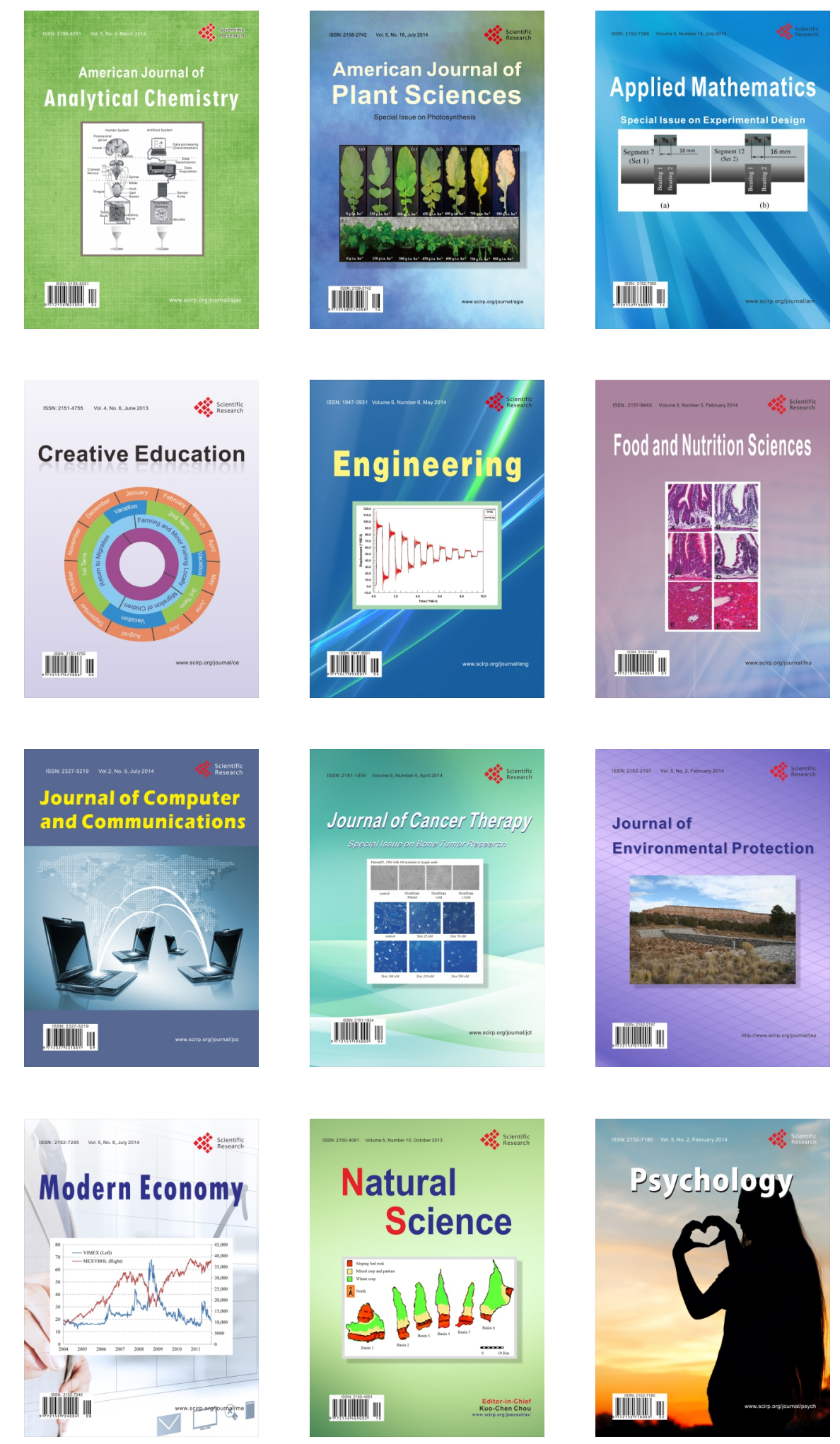